\title{
Erratum to: Neospora caninum causes severe economic losses in cattle in the humid pampa region of Argentina
}

\author{
Dadin Moore • Michael Reichel • Ernesto Spath • \\ Carlos Campero
}

Published online: 30 December 2014

(C) Springer Science+Business Media Dordrecht 2014

\section{Erratum to: Trop Anim Health Prod DOI 10.1007/s11250-013-0353-z}

In the published version of this article, there were errors in the Abstract section as well as in Table 2 and Table 3. The Abstract and tables are corrected in this erratum.

\begin{abstract}
This work estimates the economic losses due to Neospora abortions in the humid pampa region of Argentina. The total dairy and beef cattle population at risk of abortion is $1,771,326$ and 9,726,684 head, respectively. In dairy cattle, there was an $8 \%$ risk of experiencing abortion due to a variety of causes, but $16.5 \%$ of them were due to Neospora caninum. The economic losses were
\end{abstract}

estimated at US\$1,415 $(1,400-1,431)$ per abortion, which equates to a total loss of US\$33,097,221 $(15,622,600$ $-119,349,693)$ for the dairy industry at the humid pampa region of Argentina. In beef cattle, the overall risk of abortion was estimated to be $4.5 \%$ for all pregnancies, whereas $6.7 \%$ are specifically due to $N$. caninum, with an economic loss of US\$440 (range, 150-730) per abortion. This amounts to an annual loss to the beef industry of US $\$ 12,903,440$ (range, 1,130,700-42,070,630) in the same area. The results of this study show that Neospora infections and thus abortions cause severe economic impacts in the dairy and beef industries in the humid pampa region of Argentina, which is one the most important areas of cattle production in the world.

The online version of the original article can be found at http://dx.doi.org/ 10.1007/s11250-013-0353-z.

D. Moore $(\bowtie)$

Consejo Nacional de Investigaciones Científicas y Técnicas

(CONICET), C1033AAJ, Buenos Aires, Argentina

e-mail: moore.dadin@inta.gob.ar

M. Reichel

School of Animal and Veterinary Sciences, University of Adelaide,

Roseworthy Campus, Roseworthy, SA 5371, Australia

E. Spath $\cdot$ C. Campero

Instituto Nacional de Tecnología Agropecuaria (INTA),

7620 Balcarce, Argentina 
Table 2 Estimated direct and indirect costs of $N$. caninum abortions in beef and dairy cows in the humid pampa

\begin{tabular}{|c|c|c|c|c|}
\hline & \multicolumn{2}{|l|}{ Dairy (US\$) } & \multicolumn{2}{|l|}{ Beef (US\$) $)^{\mathrm{a}}$} \\
\hline & Option "A" & Option "B" & Option "A" & Option "B" \\
\hline Fetal loss & 250 & 250 & 150 & 150 \\
\hline Professional assistance & Not done & 50 & Not done & 50 \\
\hline Laboratory diagnosis & & 140 & & 140 \\
\hline Pregnant heifer replacement & Not replaced & 1,441 & Not replaced & 950 \\
\hline Loss of milk yield associated with/due to abortion & $1,150^{\mathrm{b}}$ & Milk yield from the heifer & - & - \\
\hline Proceeds from selling cow in good body condition & Not sold & 450 & Not sold & 560 \\
\hline Total US\$ & 1,400 & 1,431 & 150 & 730 \\
\hline Mean & & 1,415 & & 440 \\
\hline
\end{tabular}

${ }^{a}$ There were no data related to the costs associated with the time lost in the production of beef calves due to delays in replacing culled affected animals with new pregnant heifers

${ }^{\mathrm{b}}$ Mean of losses associated with the loss of milk yield due to abortion in heifer or cow $(17.1 \mathrm{~L} \times \mathrm{US} \$ 0.22 \times 305$ days — milk yield $)$

Table 3 Estimated economic losses due to N. caninum-related abortions in dairy and beef cattle in the humid pampa of Argentina

\begin{tabular}{|c|c|c|c|c|c|c|}
\hline Cattle & $\begin{array}{l}\text { Cattle at } \\
\text { risk }(n)\end{array}$ & $\begin{array}{l}\text { Median total } \\
\text { abortion risk } \\
(\%) \text { (range) }\end{array}$ & $\begin{array}{l}\text { Median abortion } \\
\text { risk by } \\
N . \text { Caninum } \\
(\%) \text { (range) }\end{array}$ & $\begin{array}{l}\text { Median number of } \\
\text { abortions due to } N \text {. } \\
\text { caninum (n) (range) }\end{array}$ & $\begin{array}{l}\text { Mean cost per } \\
\text { abortion (US\$) } \\
\text { (range) }\end{array}$ & $\begin{array}{l}\text { Estimated economic } \\
\text { losses (US\$) (range) }\end{array}$ \\
\hline Dairy & $1,771,326$ & $8(5.0-12.9)$ & $16.5(12.6-36.5)$ & $23,382(11,159-83,403)$ & $1,415(1,400-1,431)$ & $33,097,221(15,622,600-119,349,693)$ \\
\hline Beef & $9,726,684$ & $4.5(2.5-7.5)$ & $6.7(3.1-7.9)$ & $29,326(7,538-57,631)$ & $440(150-730)$ & $12,903,440(1,130,700-42,070,630)$ \\
\hline
\end{tabular}

